\title{
The Intellectual and Educational Resources as an Institutional Factor of Innovative Economy Formation
}

\author{
Boris Mihailovich Zhukov \\ Valeriy Petrovich Basenko \\ Aleksandr Anatolievich Romanov \\ Yana Valerievna Babayan \\ Natalia Georgievna Fomichenko
}

Southern Institute of Management

Email:vs.novikov@mail.ru

\section{Doi:10.5901/mjss.2015.v6n3s6p283}

\begin{abstract}
Quality of an innovation and its efficiency depend in a decisive way on quality and degree of novelty of the knowledge that is been its basis. New knowledge, such as the discovery of electricity, the managed nuclear reaction, the creation of electronic computers, the mean transition of mankind to the qualitatively new step in development. The new knowledge is equivalent to new economy of knowledge to power, material and labor costs, directly allowing replacing them with knowledge how it is possible to gain the same or bigger effect at the same or smaller costs of energy, materials and live human labor. In the economy of knowledge, the corporate and national wealth depends on accumulation and use of the knowledge making the main cost of intellectual capital. Despite a set of determinations and classifications of intellectual capital, most of the authors adheres to that point of view, that the intellectual capital includes human capital and the structural capital.
\end{abstract}

Keywords: resource, institutional, economy, technologies.

\section{Introduction}

The idea at the beginning of the XXI century is understood as the innovation economy or economy of knowledge, gives the program of the World Bank "Knowledge for Development" (Knowledge for Development - K4D). By means of Knowledge Assessment Methodology - KAM, the Knowledge for Development programs performs an assessment of the economy of this country regarding its compliance with requirements imposed by the economy of knowledge. Thus 109 structural and quantitative parameters calculated for 146 states are used. Comparison can be carried out also on fourteen indicators, characterizing four basic principles of economy of the knowledge or the innovation economies given in Table 1 on the basis of which the Index of Economy of Knowledge (IEK) is calculated (Indicators of the innovation activity, 2013).

Table 1 Principles and indexes of the innovation economy

\begin{tabular}{|l|l|}
\hline \multicolumn{1}{|c|}{ Characteristics of the principles } & \multicolumn{1}{|c|}{ Izndexes of the innovation economy } \\
\hline Principle 1. Economic system and institutional mode \\
\hline $\begin{array}{l}\text { The economic system and institutional state system have to provide } \\
\text { incentives for effective use existing, and also acquisitions new knowledge } \\
\text { and their applications in economic activity for rise in performance, } \\
\text { improvement of quality, introduction of innovations and start of the new } \\
\text { enterprises }\end{array}$ & $\begin{array}{l}\text { Tariff and non-tariff barriers. The quality of regulation } \\
\text { of the economy. Rule of law }\end{array}$ \\
\hline $\begin{array}{l}\text { Principle 2. Education and skills } \\
\text { The population of the country needs education and skills that will allow } \\
\text { them to create and exchange knowledge, and also with benefit to using } \\
\text { them }\end{array}$ & $\begin{array}{l}\text { Percent of the competent population. } \\
\text { The population percent with secondary education. } \\
\text { The population percent with the higher education }\end{array}$ \\
\hline
\end{tabular}




\begin{tabular}{|c|c|}
\hline \multicolumn{2}{|l|}{ Principle 3. Information infrastructure } \\
\hline $\begin{array}{l}\text { The dynamic information infrastructure is necessary for simplification of } \\
\text { effective communication, distribution, and information processing }\end{array}$ & $\begin{array}{l}\text { The number of phones for } 1000 \text { people. } \\
\text { The number of computers for } 1000 \text { people. } \\
\text { The number of Internet users on } 1000 \text { people. } \\
\text { The monthly cost of "Internet basket" (10 hours an } \\
\text { hours "peak" and } 10 \text { hours per the rest of the time). } \\
\text { Availability of services of the "electronic" government. } \\
\text { Percent of expenses of information and } \\
\text { communication infrastructure from GDP. }\end{array}$ \\
\hline \multicolumn{2}{|l|}{\begin{tabular}{|l|} 
Principle 4. The innovation system \\
\end{tabular}} \\
\hline $\begin{array}{l}\text { The innovation system of the country (firms, the research centers, } \\
\text { universities, think-tanks, consultants and other organizations) have to be } \\
\text { capable to reveal the growing stock of global knowledge, to assimilate and } \\
\text { adapt it to local requirements, and also to create new technologies for } \\
\text { new products and processes, competitive in the foreign and domestic } \\
\text { markets }\end{array}$ & $\begin{array}{l}\text { License fees and income, US dollar per capita. } \\
\text { Articles in technical journals, on one million people. } \\
\text { The patents granted to national applicants by } \\
\text { Department of the USA according to patents and } \\
\text { trademarks for one million people }\end{array}$ \\
\hline
\end{tabular}

KAM Methodology constantly develops; the new indicators are allowing more precisely estimating a level of development of the economy of knowledge is brought into it. Of particular interest is the tool, which has allowed making a comparative analysis of changes in any indicator, since 1995, or since its introduction, to date over time. A special place is given to the analysis method of the authors of modern information and communication technologies in connection with their role in the innovation economy.

The quality of an innovation and its efficiency depend in a decisive way on quality and degree of novelty of the knowledge; that is been its basis. New knowledge, such as the discovery of electricity, the managed nuclear reaction, the creation of electronic computers, the mean transition of mankind to the qualitatively are a new step in development.

The new knowledge is equivalent to the new economy knowledge power, material and labor costs allowing directly replace them with knowledge how it is possible to gain the same or bigger effect at the same or smaller costs of energy, materials and live human labor.

In the economy of knowledge, the corporate and national wealth depends on accumulation and use of the knowledge making the main cost of intellectual capital.

Despite a set of determinations and classifications of intellectual capital, most of the authors adheres to that point of view that the intellectual capital includes human capital and the structural capital. As a part of the last usually allocate organizationally and client (consumer, market) the capital.

The human capital includes unformalized knowledge, abilities, skills, experience, qualification and employees abilities of the organization. That part of the structural capital, which is carried to the organizational capital, includes the formalized knowledge of employees expressed in a different form. The intellectual property of the organization - objects of the patent law, author's right, the neighboring rights; know-how (know-how), etc. The organizational capital also includes a system of the financial relationship of the organization, philosophy of management and its corporate culture, including the capability of the organization to self-training. The second component of the structural capital - the client capital - integrates that formalized knowledge of the personnel of the organization, which are connected, mainly, with organization activity in vendor relations and clients. The intellectual property makes the basis of the organizational capital. Objects of intellectual property are on sale and bought in the intellectual property market, which it is also possible to call the market of innovations, other scientific and technical achievements.

\section{Market of Intellectual Property}

The intellectual property market is a set of sellers and buyers of the protected results of intellectual activity containing the new knowledge realized in objects of intellectual property, on which action of intellectual property rights extends.

Act as the main subjects of the intellectual property market:

- The state on behalf of state bodies, which develop the laws and other regulatory, legal acts, directed at the regulation of activity of subjects of managing and intellectual property protection. The budget of the state is filled up by the taxes and fees levied on all accounting entities;

- The enterprises and the organizations which are directly occupied with the creation of objects of intellectual property and acting as sellers who offer these objects in the market of intellectual property;

- Authors of the results of intellectual activity realized in objects of intellectual property; 
- The innovation enterprises which are developing and letting out the innovation products with the use of the objects of the intellectual property purchased in the market of intellectual property; these products are sold in a commodity market and services;

- The investors (banks, pension and venture funds, corporations, the government budget, etc.) financing both developers of objects of intellectual property, and producers of the innovation products;

- Producers of counterfeit products take the unique place in the market; by its production objects of intellectual property the rights on which do not belong to these producers legally are used. The enterprise, which is letting out counterfeit products, is engaged in illegal activity irrespective of, whether there corresponds quality of these products to the set parameters of specifications.

In general, the sector of intellectual services can conditionally be presented in the form of the following scheme where intellectual business services are provided. Thus, education is allocated to particular category (figure 1)

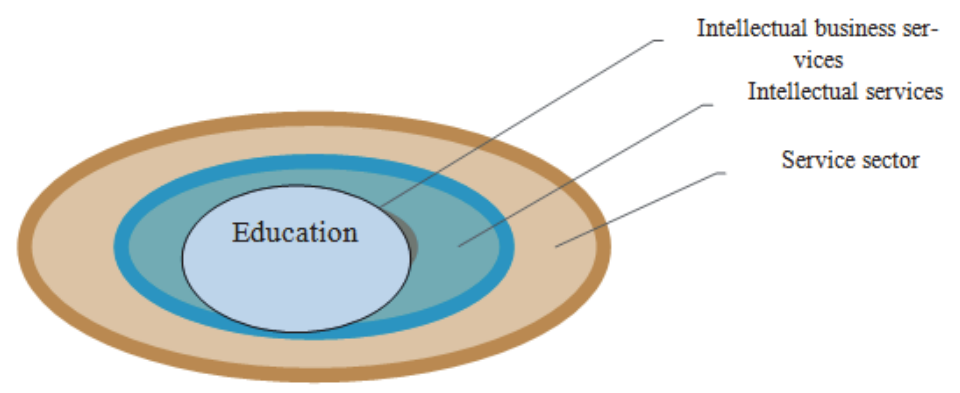

Figure 1 Ratio of the service industry, intellectual services, and education

Let's consider the main making sectors of intellectual services, intellectual business services, and educational services. Let's note that the sector of intellectual services can include not only the specified elements. Here it is possible to refer also activity of individuals, the households which are engaged in the creative services (any creativity) which are not registered by educational services tutoring's, the international teams of creative services in the field of branding (Avery Dennison) specializing in implementation of the unique decisions capable to increase attractiveness and value of a brand in the opinion of buyers.

For our research, we believe sufficient to analyze the main components of the sector of intellectual services.

1. Intellectual business services.

According to a OECD study of major trends in the service sector with an increased capacity of knowledge (knowledge-intensive service activities - KISA), or intellectual services, including research services, management consulting, ICT services, personnel management and employment, legal services, auditing and financial services as well as marketing, the leading countries on the results of 2013 are Luxembourg, Switzerland and Iceland, are far behind the countries with emerging market, such as Poland, Turkey (Figure 2).

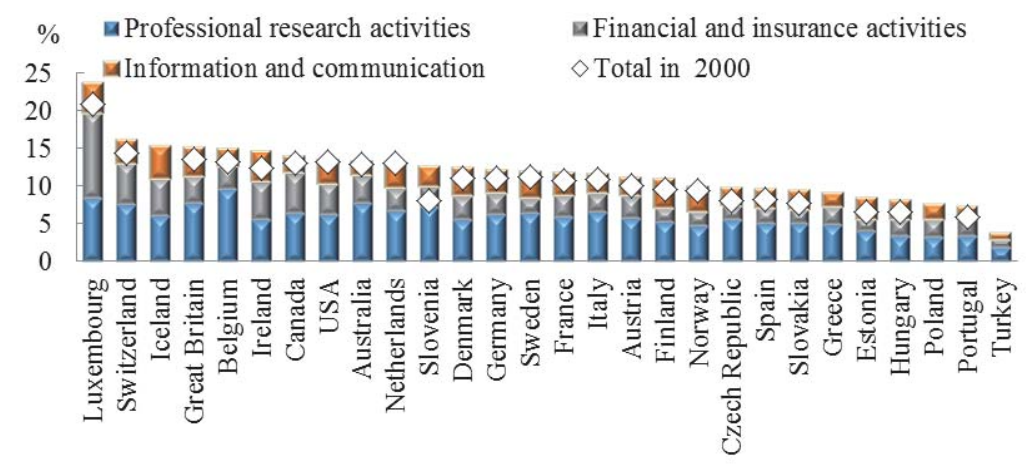

Figure 2 Service Industry Ratio, intellectual services, and education (Knowledge-intensive service activities. OECD. URL: http://www.oecd.org) 
Besides, during research it was revealed that the high-technological effectiveness of the industry in which intellectual services are attracted, the more essential them influence on the innovation development, and also speed of updating of the knowledge-intensive services is higher.

Intellectual services in the economy of knowledge carry out very important function consisting in forming of flexible innovation mechanisms in the conditions of changing the institutional and market modes.

Thus according to L. Mindeli and L. Pipia for providing a necessary level of development of intellectual services it is necessary to implement accomplishment of the following conditions:

- $\quad$ "Competitive environment and openness of the markets;

- High innovation activity of the companies working in the field of services;

- Universal application of information and communication technologies;

- The flexibility of organizational structures and personnel;

- Permanent professional training of workers and growth of their qualification level;

- Availability of the adequate motivational and stimulating mechanisms in work with the personnel of the companies" (Mindeli L.E., Pipia L.K., 2007).

It should be noted that intellectual business services are of particular interest not only owing to their high innovation, active development, and also progressive view of the compensation which is actively motivating employees but also owing to that fact that they are the major actors in the innovation systems, both on regional and on sectoral levels, promote implementation of the innovation activity of the client, and also acceptance of its participation in production and dissemination of knowledge in system (Doroshenko M.E, 2011).

In the conditions of new forms development of communication and informatization, and also expansions of economic space for activity of intellectual business services, are allocated the new directions of service innovations: which main categories are provided by the innovations oriented to standardization of the rendered services, the second — on their customization.

The first direction assumes the activity aimed at bringing the design of service to the replicated format. At the heart of the second the individualization (customizations) of production, i.e. small-lot production of products or even release of single exclusive goods is mortgaged.

The individualization gradually becomes more and more popular, first of all, in advanced market systems, reflecting the thereby active development of the economy of knowledge. "By some estimates, now the share of mass production in developed countries makes already no more than a third of total amount of the let-out products, the rest is the share of the small-scale products (from 10 to 2000 pieces) oriented to tastes of this or that contingent of buyers, thus the cycle of production is considerably reduced" (V. G Horos., 2011).

The data obtained by National Research University Higher School of Economics during polls of producers of intellectual services in Russia "confirm that both tendencies (to industrialization and an individualization) in sector of intellectual services are approximately equivalent" (V. G Horos., 2011).

Table 2 Ratio of the Standard and Customized Products in the Russian sector of intellectual services (\%)

\begin{tabular}{|l|c|c|}
\hline & The standardized services & The customized services \\
\hline Advertising services & 45.7 & 54.3 \\
\hline Marketing services & 36.5 & 63.5 \\
\hline Services in the field of ICT & 59.7 & 40.3 \\
\hline Auditor services & 60.4 & 39.6 \\
\hline Services in personnel recruitment & 40.3 & 59.7 \\
\hline Engineering services & 47.1 & 52.9 \\
\hline Services of financial intermediation & 50.1 & 49.9 \\
\hline Legal services & 23.4 & 76.6 \\
\hline Services in the field of real estate & 48.3 & 51.7 \\
\hline Design services & 59.2 & 40.8 \\
\hline Weighted average on sector & 47.0 & 53.0 \\
\hline
\end{tabular}

For this period research in the sphere of intellectual services extremely for Russia as affects priority categories knowledge, human capital and innovations. "Insufficient use of intellectual potential of the country, modernization results in low competitiveness of the Russian sphere of intellectual services on the world scene and by that slows down transition from an industrial stage of development of society during post-industrial age" (Chernyak T.V., 2013) 


\section{Educational services.}

"The accelerated forming of economy of knowledge means the accelerated forming of "the innovation and educational enterprises" as primary production cells of economy of knowledge - with emergence of a complex system of the economic relations based on their specialization and cooperation" (Levina M. V., 2011).

Respectively, the measure of responsibility of educational institutions "for quality of knowledge which are gained by the graduate as the higher education becomes one of the necessary strategic resources, raises, providing perspective innovation development and competitiveness as graduate in labor market, and the countries on the international scene" (Levina M. V., 2011).

With respect thereto before modern educational institutes, the new tasks, first, connected with the creation of the innovation internal organization and development of the innovation policy form. Thus the purpose of the innovation policy of any educational institution in these conditions has to be defined not only training of highly qualified competitive specialists, but also complex development of a human capital, generation of scientific knowledge, technology and other innovations. Thus, before educational institutions there is a problem of the judgment of new methods and technologies of training. Successfully modern methods and analytical approaches, which can be applied as in the field of scientific search, and education, develop.

Education becomes the key factor defining not only the further improvement of quality of life of the population, but also human development, successful employment of specialists in the conditions of the economy based on knowledge.

For today on the population share with the higher and postgraduate professional education ( $51 \%$ of all manpower at the age of 25-64 years) Russia is higher than a level of a number of the leading foreign countries, such as Canada, Japan and advances the USA, Great Britain, Israel.

At the same time, the situation in this area is characterized by a number of negative trends that could potentially devalue a competitive advantage.

The quality of education at all levels - from basic, primary and secondary professional education continues to decrease to the higher and postgraduate professional education. On this background an important exception is sharp breakthrough as reading and understanding of the text in elementary school - by results of PIRLS-2011 Russia won first place (together with Singapore and Hong Kong) having risen in comparison with 2001 at once by 13 places (PIRLS) 2011). It means that starting positions of the Russian school students "at the exit" from preschool and family education; it is better than at most of the contemporaries in other countries. The basic education of the following levels these benefits. So, "the Russian school students of the senior classes concede to the foreign contemporaries from developed countries on the majority of indicators of level of knowledge of mathematics (the 38-39th place from 65 countries), to the same skills of work with the text (the 41-43rd of 65), to knowledge in the field of the exact sciences (the 38-40th of 65)"( SUPPORT OF RUSSIA 2015).

Unlike a number of developed countries where shortcomings of basic education of a certain part "are corrected" in the system of the higher education, in Russia and high school education degradation tendencies were observed until recently. According to the international ratings, the Russian higher education institutions practically do not get to the first two hundred global leaders.

The lack of financing is significantly aggravated by structural problems, including outdated management models educational process, shortage in an education system of modern personnel, including managerial. Speaking more widely, the education system is insufficiently oriented to requirements satisfaction of the development of the economy of knowledge. 2015).

Thus education quality evaluation which the Russian employers, in general, give low ( SUPPORT OF RUSSIA

Except quality of education the significant role for future development is played also by the vital installations created by the person, behavior models which promote transition to economy of knowledge and improvement of quality of life in the country.

The core competencies of new society determined by the project of strategy "the Innovation Russia-2020" have to become:

- Capability and readiness for life-long education, continuous improvement, retraining and self-training, professional mobility, the aspiration to the new;

- The capability to critical thinking;

- capability and readiness for reasonable risk, creativity, and enterprise, ability to work independently and availability for service in the team, availability for service in the highly competitive environment;

- broad foreign language skills as communication instruments of effective participation in globalization 
processes, including the capability to free household, business and professional communication in English.

The successful solution of tasks of forming of competencies of "the new person" requires modernization of the policy realized by the state in the field of education in a number of the key directions:

- Expansion of practice of training at the leading international universities, first of all at the level of postgraduate study, development and sale of system of measures for attraction them for work in key Russian higher education institutions and the scientific organizations. This package of measures includes, including, increase of the general attractiveness of Russia for such specialists, development of institutes and infrastructure that will promote in turn improvement of quality of life and transition to economy of knowledge

- For the purpose of increase of availability of quality professional education and expansion of its resource base it is going to intensify work on expansion of scales of the state support of development of mechanisms of educational crediting, including master programs and programs of additional education, taking into account possibility of financing of training at the leading international universities.

- Development of a system of life-long education, the creation of effective system of incentives and conditions (infrastructure) for permanent retraining and advanced training for all economically active population will become a key task in the education field.

Table 3. Target indicators of implementation of the tasks

\begin{tabular}{|c|c|c|c|c|}
\hline Name of the indicator & 2010 & 2013 & 2016 & 2020 \\
\hline Scope education of the population aged5-14 years, \% & $93.6(2009)$ & 96,6 & 98 & 100 \\
\hline Average monthly nominal accrued payroll in education, in \% to a salary in economy & $71,3(2009)$ & 75 & 80 & 100 \\
\hline $\begin{array}{l}\text { Share of the population participating in life-long education (for the last } 12 \text { months), in } \% \text { of } \\
\text { number of respondents at the age of } 25-64 \text { years }\end{array}$ & $24,8(2008)$ & 30 & 40 & 55 \\
\hline
\end{tabular}

Source: Strategy of the innovation development of the Russian Federation for the period till 2020 (utv. the order of the Government of the Russian Federation of December 8, 2011 N 2227-p)URL:http://www.garant.ru/products/ipo/prime/ doc/70006124/

Thus, key conditions of long-term prosperity and stability are the long-term investments in the material, human and social capital, openness for the innovation activity and transformations promoting creation of effective material and moral incentives for inflow of the most qualified specialists, active entrepreneurs of creative youth in the economy sectors defining its development and also in providing this development science and education that as a result will lead to improvement of quality of life of the population and creation of economy of knowledge.

Besides, in connection with expansion of a sphere of influence of information and communication new technologies of training, in particular, distance training thanks to which become achievable generality of education, increase of its quality, the offer of diverse educational programs, including for those who are owing to certain reasons cannot visit educational institutions are allocated. However, practice testifies that this technology of training demands further improvement and improvement of quality characteristics, after all as Kudashov V. I. notes many moments connected with implicit knowledge can be transferred only in processes of interpersonal communication (Kudashov V. And., 2012).

In turn application of information and communication technologies becomes a certain challenge for an education system, demanding additional finance costs and simultaneous increase of efficiency, besides there is a problem of competent functioning in information space and protection of the intellectual rights to development in this sphere.

At the moment, according to the analytical report "The future of the higher school in Russia: an expert look", development of system of Russian education is possible in the following directions:

- the catching-up modernization;

- achievement of local leadership;

- $\quad$ the movement to "cognitive society."

1. The concept of "the catching-up modernization" assumes growth of a demand of personnel for the industry and the service industry, the increasing need for target training of specialists for hi-tech sectors; professional training of migrants; rendering the state support to the advanced entrepreneurial universities which are closely interacting with business by structures and providing modernization of key branches of economy.

2. "Achievement of local leadership" is connected with carrying out a cardinal education reform (decrease in falsification of education, development of the innovation and business activity trained in the course of 
education); expansion of a share of educational programs for adults and representatives of the senior generation; education and inculturation of migrants; forming of group of the leading universities (federal, research) which are the centers of integration of education, science and innovations and together with commercial sector of the perspective directions of development of economy providing achievement of local technological leadership on a row.

3. "The movement to "cognitive society": expansion of civil liberties; decrease in a role of educational bureaucracy, forming of networks of leader groups and meta university professional communities; creation of system of the information and analytical Internet portals, federal and regional the "virtual universities" providing access to knowledge and education to representatives of all age and social groups; transition to mass forming of bases of research, project, managerial competencies; emergence of large regional university complexes which will become the centers of technology and regional development" (Kudashov V. And., 2012).

So, the carried-out analysis showed that as basic elements the sector of intellectual services includes intellectual business - services and educational services, they are considered as the institutional resource of forming and development of economy of knowledge providing reproduction of knowledge - their generation, distribution (dispersion, diffusion), accumulation and use in different types of activity. In addition the sector of intellectual services includes intellectual services of individuals, including creative services (writing of fairy tales under the order, congratulatory verses, scenarios of carrying out office parties, etc.), not registered intellectual services (tutoring), but they do not play an essential role in the movement to economy of knowledge.

\section{Marketing of Objects of Intellectual Property}

It is necessary to understand essential, qualitative distinction between the object of intellectual property and goods in which it is realized. The patent for the computer is not similar to the computer, moreover, not each person, having studied this patent, will understand what there is a speech in this invention. Similarly, drawings of the computer are not similar to the patent. Similarly, the formula of medicine has nothing in common with a tablet in which this medicine is concluded, etc.

It is obvious that the greatest need in marketing as such appears at a commercialization stage, that is a practical use of the object of intellectual property.

Features of marketing of objects of intellectual property at this stage are:

- The basic possibility of repeated sale of the same object of intellectual property to different buyers whereas the goods can be sold only once. Moreover, repeatedly sold object of intellectual property continues to remain in property of the seller, and possibility of its use is defined by the agreement between his owner and buyers;

- importance of the correct determination of time to market of object of intellectual property, thus it must be kept in mind that large corporations, as a rule, buy only absolutely new objects of the highest quality, and sell licenses after saturation by goods of own market (Tsybulev P.N., 2012);

- the considerable, sometimes estimated decades, time gap between emergence of object of intellectual property and its embodiment in goods, recognition by the consumer and receipt of commercial benefit from use of this or that object (for example, the patent for creation of the channel transistor was granted in 1930, but it was succeeded to make it only in 1952) (Tsybulev P.N., 2012);

- as a result, marketing researches of the market of objects of intellectual property have to have a futuristic focus, have to be oriented to further perspective, anticipate development of science and equipment for 5-15 and more years, to be very sensitive to emergence of the opening and essentially new inventions creating premises for creation of unknown at the time of carrying out researches of generations of equipment, products, services, subjects of culture and life, and also conditions and quality of life of the population;

- marketing research have to consider social effect from emergence of this or that object of intellectual property, consider the predicted changes in needs of the person and society in such objects for the purpose of ensuring competitiveness of future goods in which these objects will be used;

- at determination of the price of object of intellectual property it is necessary to consider that it depends on capability of object to save live work and material resources in the field of production that does this object unique and gives it to the owner of the benefit before other developers;

- the fast obsolescence of objects of intellectual property demands from the marketing specialist of acceptance of timely measures on protection of an exclusive right to results of intellectual activity, and also determination of optimum term of a conclusion of object to the market; 
- many objects of intellectual property can be on sale in several markets, for example, the book can be offered publishing house and a film studio at the same time that it is necessary to consider in marketing plan development.

- Marketing of object of intellectual property from the seller aims to find the buyer for this object, and from the buyer - to find the object suitable for the price and quality. Both tasks equally difficult as the seller has to notify a significant number of buyers on the object of intellectual property to provide advantageous conditions of sale, and the buyer has to know very well potential suppliers of the objects interesting him not to pass the advantageous offer and to be ahead of competitors. In practice, such problems are solved by adjustment of long-term stable relations of sellers and buyers, whether it be objects of author's right or industrial property.

To use an object of intellectual property in own production or to sell the rights to it - a difficult task. The choice of the possible option of use of the object of intellectual property depends on results of marketing researches that have to be that more carefully and fully, than this object in the studied market is more perspective. Especially it belongs to the objects of industrial property protected by patents and know-how.

Comparison of volumes of profit, being at the command the owner of object of industrial property at sale of the license and its use in own production, testify that in the second case the profit is shared between the licensor and the licensee in the ratio (10-3 0): (70-90) \% whereas in the first it remains at the owner completely (Mukhopad V.I. and Pegasova L.V., 2008). Nevertheless, in some cases sale of the license for the object of industrial property is preferable or inevitable.

In the conditions of Post-Soviet reality of the beginning of the XXI century are the most often found reasons: absence or a lack of means at the owner for the self-produced organization of products for the patent or other object of intellectual property; inability to sustain the competition to foreign producers at the price and especially goods quality or services; not demand of object of industrial property the state or other customer for the same reasons; lack of own production; the heavy taxes, the customs duties and other charges doing production unprofitable, etc.

Making the decision on sale of the license for object of intellectual property or its use in own production, it is also necessary to consider such circumstances as expenses on transportation and creation of customer services for service of the exported products. When the rights to object of intellectual property are transferred according to the non-exclusive license, it is necessary to compare production volumes in own production and according to the license, and also the territory of action of the non-exclusive license and to compare potential profit on sale of own products in these territories to profit on sale of the license.

In spite of the fact that one of the strongest incentives for sale of licenses is deficit of means for production organization of new products, the decision on sale, nevertheless, has to be made deliberately, taking into account a number of factors, including economic and military safety of the country. Complete freedom of the developer in the matter so, and maybe is more unjustified, as both unreasonable restrictions and bans from the state.

\section{Market of the Innovation Ideas}

The theory is some explanation of a real-life object or the phenomenon. Innovations exist. Any explanation of that innovations why they arise represent, what conditions predetermine their development, what factors promote it and what on the contrary - disturb innovations, etc. - all this will represent the innovation theory. Look at any monograph devoted to innovations - there is anything: talk about types of innovations, on the innovation structures, on an innovation these processes, - about everything, besides, that promotes an explanation of an essence of innovations. Therefore the theory as such is not present, there are its separate elements. Those monographs that appear near at hand and in a certain measure apply to an innovation theory statement role, in my opinion, cope with it badly. But once they are, the process of formation of innovation theory suggests itself - to carry out critical and constructive analysis of the merits of the above, and on this basis to give a proper understanding of the theory of innovation.

The propensity for innovation and their ability to exercise - if necessary, a sign of the company - so begins the first chapter, entitled Theory of Innovation ", one of the few books, which sets out the theoretical materials of the plan in terms of innovation (Theory and mechanism innovation, 2009, p. 4). Moreover, this first phrase raises doubts - we after all know that many centuries of a human civilization many craftsman's enterprises existing in the conditions of religious dogmas and tough shop restrictions quietly did without innovations.

Forward development of innovations due to unlimited needs of the person as a certain reality is observed the last two - three eyelids, were not observed the whole millennium at all. What - unless in X or XI century at the person, a family and society was not requirements? Were! However, they did not force "to invent all new and more effective methods of satisfaction of these requirements at all" (Todosiychuk A.V., 2005). Moreover, inventors of these new 
methods most often finished life on fire or an executioner's block. Mind refinements if they were beyond religious dogmas, were cruelly punished by society. Therefore requirements "the person, a family, society" are not the reason for innovations at all. Alternatively, if attentively to consider this cause and effect relationship, we will be convinced that it is indirect, mediated. Speaking about the innovation theory, we have to apply it as a certain universal theory, the theory that is right at all stages of humanity development, and not just at that stage that we endure today.

As innovations are a response to the competition of market economy, it is necessary to consider them from positions of inclusion in economic circulation, including considering them as goods on which demand forms. For these goods rivalry between participants of the market is performed, and it is in full included in a difficult whirl of competitive struggle. Considering innovations quite so, it is possible to understand the properties of innovations important from positions of forming of the basic innovation theory.

\section{Value of the Person as New Institutional Paradigm}

The newest concept of social development is based on the repeated importance and pricelessness of human life. This value becomes the modern civilization prevailing in development.

The importance of human life is realized today and in the scientific community, and in the field of the government, but the concept "importance of human life" is treated ambiguously. Most of scientists and politicians agree that the importance of the person in a broad sense includes preserving or multiplication not only numbers of the people making him, but also their health and well-being, intellectual and moral potential of society and each certain person, capability of the people to successful development of all world achievements and to active participation in their development. However all these objectives can be achieved only if saving of the people in confined sense if the people do not decrease quantitatively that is if it is not reduced is provided, and it is even better - country population size increases. The analysis of a demographic situation is necessary for Russia for many reasons including because the population size of Russia decreases: in 1989 the population made 147 million people and was reduced by 2009 to 141.9 million, the natural wastage in 2003 made 888.5 thousand people in a year; in 2004 - 792.9; in 2005 - 846.6; in 2006 - 687.0; in 2007 470.4; in 2008 - 362 thousand persons. (Russian Federal State Statistics Service, 2013). The natural wastage was blocked by migratory flows of the population. Therefore, the population decrease of Russia occurred not so promptly. Dynamics net - coefficient testifies that the Russian birth rate is lower than the level of simple substitution of generations now, and there is a natural question, whether it is capable to raise in the near future so to provide at least not decrease of number of Russians that, undoubtedly, has to serve one of the criteria of "the importance of human life". On life expectancy, Russia is in the world table outside the first hundred.

Thus the level of cash income per capita exceeding the average Russian value developed in 17 regions, and in 2 regions it did not also reach a half from an average over the country. (Science Indicators, 2013). An indicator of stratification of society is also Jeanie's coefficient that in 2013 made 0.439 . From the macroeconomic point of view exceeding of the coefficient of Jeanie more than 0.35 starts slowing down economic growth, generates social tension and distracts attention from the measures conducting to increase the income. The most noticeable social and economic result of reforms is polarization of the income of the population and a social break of society that actually led to emergence not "New Russia", and "Two Russia", resisting and more and more dispersing on the to behavior, preferences, and orientations. Two levels of living, two countries - the country rich and the country of poor people which income does not reach a subsistence minimum were formed. The abyss between rich and poor (the share of the second is much more share of the first) means impossibility of normal reproduction of the main part of the population and makes threat for saving of the Russian people.

Unfortunately, objective data show that for the last decades moral level considerably fell in Russia. Not accidentally, in statements of scientific different political views, in sociological polls of the population moral degradation of modern Russian society is called as the main problem of modern Russia. The moral condition of our society is, first, the indicator of its general state; secondly, a consequence of the processes happening in it; in the 3rd, the basis of that expects us in the future. The history gives many examples, since the death of the Roman Empire when in general economically safe states perished as a result of falling off the moral level of the population. Only through the increase of the level of moral in society it is possible to come to saving as itself, and the population, in general, specifically taken a person.

The analysis of dynamics of "achievements" of Russia in the field of saving of the people demands the answer to a question: what to do? Private business is not interested in the solution of this problem has another purpose - profit earning. K. Marx in "Capital" noted: "The capital is afraid of lack of profit or too small profit as the nature is afraid of emptiness. However, time is available sufficient profit, the capital becomes courageous. Provide 10 percent, and the 
capital agrees to any application, at 20 percent it becomes active, at 50 percent is positively ready to break to itself(himself) the head, at 100 percent it violates all human laws, at 300 percent there is no such crime on which he would not risk, at least on pain of the gallows" (Marx K. and Engels F., 1974 p.24) an adequate image the people can carry out Function of saving of the people, controlling all programs, laws, projects. Public audit of actions of the government and the decisions made by it regarding compliance of these actions to values of the nation and national interests. It can become an efficient form of the public (civil) control allowing to fight really against arbitrary behavior of officials, corruption, will allow to stop a flow of immorality and without spirituality, to stop the industry of defect constructed on it for the sake of money crippling souls destroying morals and true culture. Any change, any innovation or technology achievement should not be used to the detriment of the person, to the detriment of the nation. That is why after Ancient Greek philosophers it is necessary to exclaim: "The person - a criterion only!". The person and a human capital are integral indicators of a condition of saving of the people, the nation.

\section{Value for Purposes of Investment in Human Capital}

People purchase these or those skills to earn more that is a basic reason of receipt of the higher education. Also the leading positions in economics, it explains law departments, faculties of management, marketing, PR. From the point of view of demand and supply of firm - buyers of work - are ready to pay a high salary to educated employees, as a marginal product of the last above. Workers - suppliers of work - will agree to high costs of education only when they expect the corresponding remuneration in the future (N. Gregory Menkyyu, 2002). Education can serve as method of career promotion also. Professional growth allows satisfying needs for the maximizing usefulness of skills and abilities as higher position means bigger professionalism and respectively, receipting of bigger return from skill. The factors stated above define the purposes of the person, which he sets in the solution of a question of implementation of human capital investments: earnings increase, career growth. The state sets for itself absolutely other tasks, namely the greatest scope educational programs of the population, standardization of standards of education, the organization of selection of the most worthy applicants for receipt of the higher education, control over quality of education. According to the Constitution of the Russian Federation, "everyone has the right to education. General availability and free of charge preschool, main general and secondary professional education in the public or local government educational institutions and at the enterprises are guaranteed" (The Constitution of the Russian Federation, Art. 43).

The state is engaged not in maximizing earnings of each certain person, but the execution of the direct functions. The main economic target is the increase in a public product. It is achievable only on condition of the high level of social development that is impossible in the absence of extensive human capital investments. Besides, the state cannot be guided by "popular" professions and has to support a necessary level of development so-so - vocational education and the directions with the low commercial return. Therefore, the purposes of the state in the field of investment into a human capital are: development of the universal standards of education meeting the requirements of the present, creation of system of selection of the best applicants for receipt of the higher education and financing of their training, implementation of "necessary investments" (in fundamental sciences, in pedagogics, in so-so - vocational education, in general primary and secondary education). In these conditions it is extremely difficult for firms to define own tasks in investment into human capital as firms face requirements about a high salary and career growth that are based on the fact of receipt of the diploma of "highly paid specialty". The Russian organizations are not inclined to employ decisions on acceptance as the new employee only based on education availability. Recently the main requirement for employment is an experience.

The main objective of firms now it is possible to call personnel recruitment under ready requirements without the possible potential of applicants. In theories of firm irrespective of the fact how they strongly differ among themselves in other respects, impact on the performance level of the worker of the production process practically is never considered. Many increase the performance, seizing new skills and improving already available directly in a workplace. Obviously, future performance can be increased only at the price of certain costs; otherwise demand for preparation would be boundless. (Gary S. and Becker D.,2003)

For effective work in modern conditions, the firm has to set for itself other tasks, namely:

- Creation of system of criteria for an assessment of the "signals" characterizing a human capital;

- Creation of system of internal resources of firm on development of human capital;

- Maximizing efficiency of use of external resources on building of human capital;

- Creation of the debugged structure of HR of management. For this purpose, the firm needs to formulate some purposes: 
It will allow satisfying optimum needs of firms for qualified personnel. Needs of workers as the purposes of the firm will match the purposes of workers will be satisfied at the same time. Besides, national objectives will also be considered as recognition of educational achievements by commercial enterprises testifies to trust to the educational system in general. At similar combination needs of individuals, the state and firms will be satisfied.

\section{References}

Gary, S. Becker (2003) Human behavior economic approach/ The state University - Higher School of Economics. Moscow. pp. 672. Doroshenko, M.E. (2011), The innovation potential of the sector of intellectual services in Russia // Forsythe of t. 5. № 4. pp. 52.

Gregorin, N. Menkyu (2002) Principles of economy/ Piter. - St. Petersburg. pp. 493.

Indicators of the innovation activity, (2013). Stat. c6. - M.: The state university - Higher School of Economics, 2013. - 428 p. - 800 copies. - ISBN 978-5-7958-0790-2. pp. 105-106.

Science indicators (2013) statistical collection. - Moscow: National research university "Higher School of Economics". pp. 400.

Kiselyov, V.N., Rubvalter D.A. \& Rudensky O.V. (2009) The innovation policy and national innovation systems of Canada, Great Britain, Italy, Germany and Japan//Information and analytical bulletin. №6. pp. 3.

Constitution of the Russian Federation [Electronic resource]: the complete text is located at the address-HTTP://www.constitution.ru/gt;

Kudashov, V.I. (2012) Strategy and scenarios of development of the higher education in the conditions of globalization//education Philosophy. № 6. pp. 82.

Levina, M.V. (2011) Intellectual services as a key factor of post-industrial society Economic researches. №5. pp. 6.

Marx, K. (1974) Capital,t.1, Ch.24.Marx K. and Engels F., Soch., 2prod.,t.23 Edition second M.: Publishing house of political literature. Mingdeli, L.E. \& Pipiya L.K. (2007) How to keep the Russian fundamental science? Organization of research activityЖ. №2. pp. 22-26.

Mukhopad, V.I. \& Pegasova L.V. (2008) Intellectual property as a key resource of modernization of the Russian economy//Patents and licenses. No. 8. pp. 34-36.

Support of Russia. URL: http://www.opora.ru (date of the address: 8.03.2015).

Peter, F.Druker (2007) Effective managing director. Book Chamber International. pp. 91.

Regions of Russia (2013). Socio-economic indexes. Statistical collection. M.: Rosstat pp. 990.

Taylor, Frederik Winslow (2004). Principles of scientific management [Electronic resource] / F.U. Taylor. - Electron. St. Petersburg.

http://dl.unilib.neva.ru/dl/quality/management/PrNauchnMen/prnauchnmen.html>.

Theory and mechanism of innovations, (2009) pages 4. / Under the editorship of the Prof. S.G. Svetunkov. - Saint-Petersburg State University of Economics 2009.-103 p.

Todosiychuk, A.V. (2005) Theoretical and methodological problems of the development of innovative processes in education. M.: Orgservice. pp. 125.

Tsybulev P.N., (2012) Assessment of intellectual property - M.: Institute of Intellectual property and right,2012 - 192 p.

HorosV.G. (2011) Modernization in Russia and Japan (civilization Aspects)//World economy and the international relations. № 9. pp. 75.

Chernyak T.V. (2013) The innovation policy and the innovation environment as a condition of innovations in higher education institution..//Education philosophy. № 2. pp. 205

Progress in International Reading Literacy Study (PIRLS) 2011) http://www.pirls.org/ 
